\title{
MALARIA HET BELETSEL VOOR SURINAME'S BLOEI
}

DOOR

\author{
JHR. L. C. VAN PANHUYS
}

Over dit voor het gebiedsdeel Suriname zoo belangrijke onderwerp, moge, in aansluiting met hetgeen daarover reeds in de Encyclopaedie van Nederlandsch West-Indië is vermeld, het volgende worden medegedeeld.

1. De tegenstelling tusschen de in de encyclopaedie genoemde waarnemingen van ir. jhr. Van Reigersberg Versluys en de bevindingen, door den tegenwoordigen hoogleeraar dr. P. C. Flu neergelegd in zijn in 1912 uitgekomen rapport omtrent malariaonderzoek in de binnenlanden van Suriname, is, naar wij meenen te weten, toe te schrijven aan het aan jhr. Versluys gebleken feit, dat anopheles-muggen overdag (soms zeer gevoelig) steken, doch hun steek dan geen malaria tengevolge heeft. De heer Flu, die als bij uitstek deskundige, zijn waarnemingen over een veel breeder veld dan de heer Versluys heeft kunnen uitstrekken, heeft aan de zaak groote aandacht geschonken. Hij werd op Kwakoegrond en op den Maăboberg (bij den spoorweg) in de schaduw, op klaarlichten dag, 's middags om 12 uur, bij bewolkten hemel door anopheles argyrotarsis gestoken, en zegt (blz. 33 van zijn rapport), dat de na jarenlange ervaring verkregen kennis, dat de kans malaria te krijgen alleen dan bestaat, als men zich, nadat het donker geworden is, aan de steken van anopheles blootstelt, door de eigenschap van ook bij dag te steken niet in 't minst in haar juistheid wordt aangetast. Flu beschrijft zijn onderzoek ter zake en heeft zekerheid verkregen nopens het volgende:

$a$. In de binnenlanden, en wel in de meest beruchte malariahaarden, zijn er Europeanen, die geruimen tijd in de bosschen doorbrengen en gezond blijven, mits zij zich maar streng aan den regel houden, zoodra het donker wordt zich tegen de steken te beschutten;

$b$. Gedurende het malariaonderzoek heeft de heer Flu zich 
weken lang in beruchte malariastreken opgehouden. Overdag is hij dikwijls door anopheles albipes aangevallen, maar toch nooit geinfecteerd met malaria, daar hij de voorzorg nam om, zoodra het donker werd, onder het muskietennet te kruipen. Op Kwakoegrond, waar het gedurende den regentijd ook van anopheles wemelde, werden zijn helpers en hij zelf (geen van allen hadden zij ooit malaria gehad) door zeer vele albipes gestoken. Het aantal muggen, dat overdag stak, was zoo groot, dat hij bij dag niet zonder leeren slobkousen aan kon zitten microscopiseeren en telkens moest ophouden met in de micrioscoop te kijken, om stekende muggen dood te slaan. Kwakoegrond is verder een berucht oord van malaria perniciosa. Ieder niet-immuun persoon, die er zich onbeschut enkele dagen, dikwijls ook maar een enkelen nacht ophoudt, krijgt met haast wiskundige zekerheid malaria.

2. Het is interessant, dat sommige Romeinsche schrijvers, en ook de herders in de Campagna (in Italië, waar malaria vóór de bestrijding het land bijna onbewoonbaar maakte) het vermoeden hebben gehad dat de malaria-ziekte door muggen wordt veroorzaakt.

3. Men zal vaak vernemen, dat er een zekere samenhang schijnt te zijn tusschen grondarbeid en houtkappen met malaria. Hoe is die samenhang te verklaren?

De samenhang bestaat werkelijk. Bij graafarbeid ontstaan er in voetsporen en in gaten, die bij regen of bij drassig terrein door kwelwater, kunnen worden gevuld, voor muggenlarven bijzonder gunstige gelegenheden tot ontwikkeling; eveneens kunnen dergelijke plekken bij houtkappen ontstaan, gedurende welken arbeid bovendien tal van slapende muggen kunnen worden gestoord en opgejaagd.

4. Ter voorkoming van malaria behartige men de navolgende wenken:

$a$. Draag zorg, dat ge niet door anopheles gestoken wordt, en in geen geval bij nacht.

$b$. Vermijd de nabijheid van malarialijders, die niet tegen muggen beschermd zijn.

c. Tracht anopheles-muskieten en -larven in uw omgeving te dooden.

$d$. Bevorder spoedige genezing van een malarialijder; zorg dat hij niet door muggen gestoken wordt.

$e$. Tracht uw lichaam weerstand te geven tegen malariabesmetting (sport gepaard met goede voeding; onthouding van alcohol). 
Ter uitvoering van deze voorschriften wordt het volgende aanbevolen:

I. Bescherming van uw woning, en vooral van uw slaapkamer, door draadgaas voor de vensters en een sluis van draadgaas voor de deuropening.

II. Als men 's avonds uit moet, geen lage schoenen, doch laarzen dragen en voorts handschoenen, en (desnoods) gelaat en nek door een sluier beschutten (niet bang zijn voor goedkoope lacherijtjes).

III. Vermijd het overnachten op, of in de nabijheid van dorpen.

IV. Bezig op reis steeds des nachts een muskietennet, indien ge reist met inheemschen.

V. Houd er rekening mede, dat verplaatsing bij genezing van malaria steeds heilzaam is.

VI. Verhinder nabij uw woning het vormen van muskietenbroedplaatsen (zie hieronder).

Voor bescherming tegen malaria is beschutting tegen de steken van besmette muskieten het beste en zekerste voorbehoedmiddel!

Het blindweg geregeld innemen van kinine als voorbehoedmiddel tegen malaria is af te keuren. Omtrent het gebruik van kinine als voorbehoed- en als geneesmiddel raadplege men zooveel mogelijk den geneesheer. Is een geneesheer te ver verwijderd, dan kan men, als voorbehoedmiddel, om de vijf dagen 0.5 gram kinine nemen; bij koortsaanval als geneesmiddel 1 gram, hetgeen men dan gedurende 5 maanden tweemaal per week zal moeten blijven doen. Flu geeft, in het aangehaalde rapport, blz. 117, een uitvoerige kinine-therapie. Andere geneesmiddelen (alleen op doktersvoorschrift) zijn: atebrine, plasmochine en neosalversan.

$\mathrm{Na}$ een malaria-aanval kan ankylostoom-bestrijding noodig zijn. De nadeelige werking van kinine (men neme kinine in vloeibare oplossing) op de maag kan door toediening van tien druppels zoutzuur in een wijnglas water, worden voorkomen. (Het innemen van kinine kan maagcatarrh veroorzaken, die men door zoutzuurdruppels kan tegengaan).

Voor de ontwikkeling van de malaria-parasiet in de steekmug is een temperatuur van 20 tot $30^{\circ} \mathrm{C}$ noodig.

Herhaling (zie Flu, l.c. blz. 16/17) bij gewezen malarialijders kan ontstaan door plotseling afkoeling, door zwaren ongewone arbeid en door groote vermoeienis, zelfs na jaren, en hoewel geen malariaparasieten in het bloed van den patient te vinden zijn. Zelfs de koorts kan ontbreken, maar er kunnen zich zenuwpijnen voordoen op vaste tijden en pijnen in de buurt van de vijfde her- 
senzenuw; ook wel in de maagstreek of elders (malaria larvata, gemaskerde malaria).

Zwartwaterkoorts komt vooral in Afrika bij lijders aan malaria perniciosa voor, en deze schijnt ook een gevolg te kunnen zijn van overmatig kinine-gebruik. Bij den lijder is er verval van talrijke roode bloedcellen; de urine is door haemoglobine donker gekleurd, en er doet zich geelzucht voor. Bij 25 à $30 \%$ van de aangetasten heeft de ziekte een doodelijk verloop.

Personen, die veel van malaria te lijden hebben gehad, kunnen behept zijn geworden met malariacachexie; zij zien er geel uit, hebben een gezwollen milt, zijn zwak, slapeloos, moe, lijden aan stoornissen, soms met waterzucht gepaard. Er treden soms onregelmatig koortsen op, en lijders kunnen te gronde gaan aan secundaire ziekten, zooals dysenterie.

De malaria heeft een slechten invloed op de gezondheid van de nakomelingschap; men vermoedt, dat bij de Romeinen en bij de oude Grieken de volkskracht door malaria is ondermijnd geworden. Prof. dr. C. D. de Langen van de Geneeskundige Universiteitskliniek te Utrecht schrijft ons, nabij Poena in Britsch-Indië te hebben waargenomen, dat door invloed van de malaria welvarende valleien in korten tijd tot woestenij en armoede werden gebracht.

Men zal allicht vragen: Waar komen de malariaparasieten vandaan? Dit is een ingewikkeld en moeilijk vraagstuk voor dierkundigen, waaraan Flu in zijn rapport enkele paragrafen wijdt (blz. 8-10). Een vooraanstaand onderzoeker (Luhe) is er van overtuigd, dat de malariaparasieten, die zooals wij weten een deel van hun ontwikkeling in het bloed van den mensch doormaken, phylogenetisch af te leiden zijn van flagellaten (zweep-diertjes), die in den darm van anophelesmuggen in zeer veel vroeger eeuwen huisden.

Alvorens nu de gevolgen van de malaria in Suriname te bespreken, wordt in de volgende regelen uiteengezet, hoe het overbrengen der ziektekiemen door de mug van den malarialijder naar den gezonden mensch in elkander zit.

Een malarialijder, wiens bloed dus malariaparasieten in vrij groot aantal bevat, wordt door een mug aangevallen. Na lang of kort er om heen te hebben gegonsd, gaat de mug op haar prooi zitten en duwt haar steekapparaat op een plaats, waar de huid zacht is, door die huid heen, totdat zij bloed vindt, zuigt dit bloed op en met dit bloed een aantal malariaparasieten, waaronder natuurlijk ook vele, die het vermogen hebben zweepdraden uit te 
zenden. De hoeveelheid bloed, die de mug opzuigt, overtreft dikwijls haar eigen gewicht. Ze vliegt daarna met moeite weg om in een rustig hoekje haar maal te verteren, waarmee eenige dagen gemoeid zijn.

Wat gebeurt er nu met de parasieten? Enkele slechts worden verteerd, vele en vooral de grootste vormen, zenden zweepdraden uit. Deze zweepdraden bewegen zich heftig, het gelijken, indien men ze onder de microscoop beziet, precies alen waarvan men den staart vasthoudt. Eindelijk laten zij los van de rest van het parasietenlijf en zwemmen nu als vrije alen met kronkelende bewegingen in het bloed, dat de maag der mug vult.

De zweepdraden zwemmen rond en ontmoeten op hun weg een anderen grooten parasiet, die tot dusver geen zweepdraden uitzond, omdat zij daartoe niet in staat is. In zulk een parasiet dringt de zweepdraad binnen en versmelt er mee. Daar de twee parasieten, door die versmelting thans één geworden, een eenigszins wormvormige gestalte aannemen, noemt men ze wel: wormpje. Dit wormpje gaat naar den maagwand der mug, kruipt in de diepere lagen van dien maagwand en omgeeft zich met een omhulsel, of, zooals men dit noemt, omkapselt zich. Dit kapsel en daarmee de inhoud wordt grooter en grooter, gaat uitpuilen naar den buitenkant van de muggenmaag, wordt eindelijk zeer groot en zit dan als een knop op den maagwand. Voor dit proces zijn tien tot twintig dagen noodig, al naar de hoogte der buitentemperatuur. Is die temperatuur te laag, daalt zij (zooals reeds gezegd) beneden $16^{\circ}$ Celsius, dan gebeurt van dit geheele proces niets; met de roode bloedlichaampjes worden dan ook de malaria-parasieten verteerd. Het is dus een feit, dat indien het kouder is dan $16^{\circ}$ Celsius, op de plaats, waar de mug zich bevindt, wat in het laagland van Suriname nooit voorkomt, deze vorming van kapsels uit malaria-parasieten in het muggelichaam niet kan tot stand komen, daar de buitentemperatuur er te laag voor is. Hoog op de bergen, waar lager temperatuur heerscht, zal de malaria alleen optreden bij personen, die in het laagland de besmetting met de malariakiemen hebben opgedaan.

Daar er in het binnenland van Suriname door prof. Stahel op een vliegtocht - ook de Goeje geeft er een schets van - een soort van Roirama-formatie, een tafelland of zandsteen-plateau is gefotografeerd en gezien, zooals de gebroeders Schomburgk in 1840 in Britsch-Guyana nabij de Braziliaansche grens ontdekten, dat volgens E. F. im Thurn, Among the Indians of Guiana, blz. 82, zich daar ongeveer 5000 voet boven den zeespiegel verheft, zou 
dit in de toekomst voor het gebiedsdeel Suriname misschien als gezondheids-oord, als herstellings-oord voor malaria-lijders, in aanmerking kunnen komen.

Het kapsel, dat wij zooeven bespraken, wordt grooter en grooter en berst op een goed oogenblik. De inhoud ervan is geheel anders dan in den aanvang; het wormpje, dat zich oorspronkelijk omkapselde, heeft zich binnen dat kapsel gedeeld en nog eens gedeeld en thans zien wij, dat de inhoud gevormd wordt door duizenden, zelfs tienduizenden, dunne, slanke, spoelvormige lichaampjes, de sikkelkiemen of sporozoïten. Berst nu dit kapsel eindelijk, dan komen al deze sikkellichamen vrij in de lichaamsholte der mug, welke de maag omgeeft. Maar daar blijven zij niet liggen; zij gaan met den vochtstroom mee naar de borstholte van de mug en in die borstholte naar een orgaan, dat daar in ligt: de speeksel- of giftklieren; zij doorboren den wand, die de giftklieren omgeeft, dringen in de giftcellen door, waar zij tot rust komen. Nu is de mug niet langer slechts een plaaggeest, die ons in den slaap stoort, zij is een giftmengster geworden, die slachtoffers gaat maken.

Met een vergrootglas kan men nu nagaan, hoe de mug met haar steekorgaan, dat o.a. twee zaagvormig getande werktuigen en een fijne punt bevat, in de huid dringt, waarbij zij de achterste pooten iets meer strekt. De beide zagen gaan aan 't werk, terwijl de punt tegelijkertijd in de diepte doordringt. Als de zuigbuis, die door een scheede wordt gefixeerd, zoover ingedrongen is, dat de kop der mug de huid van de gestoken persoon bijna raakt, staat de mug bijna op haar kop en is de scheede dubbel gevouwen. Er wordt nu een druppeltje van het afscheidingsvocht uit de speekselklieren in de wond uitgestort. Dit vergif veroorzaakt de brandende pijn en de zwelling, welke den muggenbeet pleegt te volgen. Waarschijnlijk is het doel van dit vergif de stolling van het bloed te beletten en dus het opnemen van vrij groote hoeveelheden bloed mogelijk te maken. Indien nu echter in het vergif ook de sikkelkiemen, waarvan wij gesproken hebben, aanwezig zijn, worden met het vergif die ziektekiemen in het menschelijk lichaam gebracht en komen zij van de steekwond uit in de aderen en vandaar in den bloedstroom. Daarmede is de inenting met de infectiekiemen der malaria geschied, en na tien of meer dagen krijgt het slachtoffer den eersten koortsaanval, weldra gevolgd door meer. Worden deze aanvallen genezen, dan is die genezing dikwijls schijnbaar; na 3 weken, soms korter, dikwijls langer, volgt er weer een nieuwe aanval, en het is lang niet ongewoon, dat een persoon, die slechts 
éénmaal gestoken is door een besmette mug, daardoor twee en zelfs meer jaren telkens en telkens weer aanvallen van moeraskoorts krijgt. Het blijkt zelfs, dat vele personen, die in het eene jaar koorts hebben gehad, in het volgende jaar weer aanvallen krijgen, en dus ook dikwijls ziek worden op plaatsen, waar de malariamuggen niet voorkomen. Daarmede is dan tevens verklaard, dat er op sommige plaatsen, waar in 't geheel geen muggen voorkomen, toch malarialijders kunnen worden aangetroffen. Anderzijds zijn er plaatsen waar millioenen muggen zijn en toch geen malaria is, doordat geen malariazieke menschen daar gevonden worden en dus de muggen de ziekte niet kunnen voortbrengen. Het kan echter ook komen, doordien de anopheles er ontbreekt en er dus enkel culex-soorten aanwezig zijn.

Het is hoogst wenschelijk, dat de tropen-bewoner en de tropenbezoeker - wij denken bij het neerschrijven van deze woorden aan wijlen den Kapitein-luitenant ter zee Eilerts de Haan en aan den heer Nyon, Gouvernements-ambtenaar - dezen verschrikkelijken vijand van den mensch tusschen en nabij de keerkringen, de anopheles, weet te onderscheiden van de, wat malaria betreft, onschadelijke culex-soort. Men ziet het aan het steekorgaan; dáár staan aan weerszijden bij beide soorten voelers of tasters, die bij culex slechts korte stompjes, doch bij anopheles even lang, zoo niet langer zijn dan het steekorgaan. Een tweede verschil leveren de vleugels op; bij culex zijn de vleugels zonder zwarte vlekjes. De anopheles heeft altijd zwarte vlekjes op de vleugels. Verder zit de culex met haar lichaam evenwijdig aan den muur; de anopheles zit met de achterpooten sterk gestrekt, zoodat men den indruk krijgt, dat zij op haar kop staat. Zooals men weet, is het alleen de wijfjesmug, die steekt en bloed zuigt. De mug legt haar eieren altijd op het water; de culex in den vorm van een vlotje of schuitje, de anopheles in rechte lijn naast elkaar liggende of elkaar slechts met de punt aanrakende eieren; de eerste 200 stuks en meer, de laatste minder dan 200 eieren. In elk jaar volgen ongeveer 5 muggengeslachten elkaar op. Eenige dagen, nadat het ei gelegd is, breekt het open en komt er een uiterst fijn diertje te voorschijn, dat in 't water gaat rondzwemmen: de muggenlarf. Hier is weer verschil tusschen de twee soorten. De culexlarf heeft een lange ademhalingsbuis aan het achterlijf; de anopheles een kort buisje. Na een aantal dagen, afhankelijk van de buitentemperatuur, verandert de larve in een zoogenaamde nimf, die ook voor de ademhaling aan de oppervlakte van het water komt, maar niet door een buis aan het achterlijf, maar door twee buisjes 
boven aan den kop ademt. Na eenige dagen splijt de pophuid open, de kop komt te voorschijn, dan de vleugels, vervolgens het eerste pootenpaar, dat op het water wordt neergezet, spoedig stappen de twee andere pootenparen er uit, en het thans volwassen dier, de mug, is gereed, zittende op haar opengebarsten en met lucht gevulde pophuid als een schipper in zijn schuitje; zij laat haar nog slappe vleugeltjes even drogen en vliegt, als deze hard geworden zijn, weg.

Kan het anopheles-wijfje haar eieren nergens leggen, doordat geen geschikte oppervlakte water voorhanden is, dan is het voortbestaan dezer muggen onmogelijk geworden. Het is gebleken, dat de muggen meestal haar eieren dicht bij de menschelijke woningen leggen, dikwijls reeds in neergeworpen conserveblikken, oude emmers, vaatwerk en scherven, waarin door den regen, regenwater is blijven staan. Vandaar dat men steeds tegen het ontstaan van dergelijke muggenbroedplaatsen moet waken.

Volkomen juist zegt Junker, dat niet het Surinaamsche binnenland ongezond is, maar dat in de muskieten, die zich in de hutten van de Boschnegers ophouden (en natuurlijk in de kiemen van malaria perniciosa, die de Boschnegers in hun bloed omdragen) het gevaar schuilt. Swellengrebel overziet het vraagstuk op uitnemende wijze in dit tijdschrift, XXII, 1940.

Het is voor geheel Suriname van belang, dat men den vijand goed onder de oogen ziet. Het gevaar, om er malaria tropica op te doen is geenszins denkbeeldig. Bedenkelijk is dat van de zijde van de Boschnegers, die ongeveer een veertiende deel van de totale bevolking uitmaken, de overige dertien veertienden door een zware ziekte kunnen worden bedreigd. De arts R. Römer heeft (zie litteratuur) in 1929 in dit tijdschrift een voorstel gedaan om te trachten het gevaar op afdoende wijze te bezweren. Voorop stellende, dat plaatsen door Boschnegers bewoond, wegens het groote malariagevaar praktisch onbewoonbaar zijn; dat zij gevaarlijke bronnen van infectie zijn voor malaria tropica, waartegen creolen en Britsch-indiërs beter bestand zijn dan Europeanen, die een hoog sterftecijfer aan die ziekte vertoonen, acht hij het noodig dat desnoods dwangbepalingen kunnen worden uitgevaardigd, op zoodanige wijze, dat Boschnegers zich noch op cultuurondernemingen, noch te Paramaribo zouden kunnen ophouden, zonder eerst geheel malaria-vrij te zijn gemaakt.

De heer Römer heeft echter niet de bezwaren naar voren gebracht, die een doeltreffende uitvoering van de door hem voorgestelde dwangmaatregelen nagenoeg onmogelijk maken. Wilde 
men bereiken wat hij beoogt, het malaria-vrij maken van elken Boschneger, die zich wil gaan ophouden in het door beschaafden bewoonde gedeelte van het land, dan zou het oprichten van controle-posten, overal waar Boschnegers de bedoelde gewesten zouden kunnen binnenkomen, onmisbaar zijn; zouden op die posten medici moeten worden gevestigd om te kunnen vaststellen, of de zich daar aanmeldende Boschneger malaria-vrij was of niet, en zoo noodig hem in observatie moeten kunnen nemen, om hem malaria-vrij te kunnen maken. Er zou dus personeel, hulp, bediening, en gelegenheid voor huisvesting c.q. voor verpleging 1 ) noodig zijn. Men behoeft niet te vragen wat dit alles zou kosten. Bovendien, met alleen den Boschneger malaria-vrij te maken, zou men nog bij lange na niet voldoende geholpen zijn. Want het is niet de Boschneger alleen, door wien de malaria tropica kan worden verspreid, maar door elkeen, die zich in het boschland heeft opgehouden. Dus door alle personen, die zich met de goud- en met de balata-industrie bezighouden, en ook de zendelingen zouden, nog bovendien, bij hun terugkeer naar de stad, moeten worden gecontroleerd en behandeld. Men voelt wel, dat zooiets niet mogelijk is.

En toch dient de bevolking zooveel het kan tegen het gevaar worden beschermd. Een ieder in Suriname dient er van te zijn doordrongen, dat de pernicieuse malaria een volk in zijn levenskracht aantast. Dat in het heerschen van die ziekte de voorname oorzaak kan gelegen zijn dat in Suriname de levensstrijd zoo zwaar is, dat er zooveel is mislukt en dat het moederland er tevergeefs zijn beste zonen, een Lely, een Idenburg, een Fock, en anderen heeft gezonden om te trachten het dochterland tot welvaart te brengen, geeft toch wel te denken!

Er schijnt slechts één oplossing te zijn: voortdurende waakzaamheid van bestuur en bevolking. Doch hier zal heel veel afhangen van de kunde, de behoedzaamheid, het inzicht en de opoffering van de medici. Mogen de geneeskundigen in Suriname hun schoone taak als geneesheer met liefde en toewijding blijven vervullen en hun de eernaam kunnen worden toegekend van de behoeders en beschermers van de Surinaamsche bevolking bij uitnemendheid.

Het zich wapenen tegen de kans van het oploopen van de mala-

1) $\mathrm{Bij}$ het dooden van malaria-kiemen in het bloed kan het voorkomen, dat andere geneesmiddelen dan kinine noodig blijken. De toediening daarvan kan alleen op medisch voorschrift en onder medisch toezicht geschieden. 
ria tropica, is niet zoo moeilijk. De steller van dit artikel is jaren lang voortdurend met Boschnegers nauw in aanraking geweest en toch van de genoemde ziekte vrij gebleven, door het betrachten van een zekere voorzichtigheid, eigenlijk onbewust, want er was toen (in de jaren 1891-1896) van de overbrenging van de ziekte door de anopheles, nog zoo weinig bekend. Ware hij wel aangetast geworden dan zou hij de gevolgen daarvan toen en op later leeftijd hebben moeten ondervinden en zou hij niet thans een bloeiende gezondheid kunnen genieten. De zaak kan echter niet beschouwd worden uit een individueel oogpunt; het malaria-gevaar dreigt (zooals hierboven werd gezegd) voor het geheele land, voor het overgroote deel van de bevolking. Het moet in Suriname zóó worden, dat het malaria-gevaar (dat van malaria-perniciosa) verdwijnt, in dien zin, dat elkeen, die het niet wil, de ziekte ook niet behoeft te krijgen.

Op het oogenblik is de toestand zoo, dat bij wijze van spreken elkeen, die zich naar het binnenland begeeft (en dus in de nabijheid van Boschnegers, of van andere dragers van de malariakiemen gaat vertoeven) malaria perniciosa oploopt. Dááraan een eind te maken, lijkt mij het grootste probleem, dat ooit in Suriname is gesteld.

Ik zou wenschen, dat er twee van de bekwaamste geneeskundigen tot buitengewone leden van den raad van bestuur werden benoemd, en een permanente Malaria-Raad, waarin alle medici zitting hadden, in Suriname in het leven werd geroepen. Het is nu eenmaal onmogelijk - er is hierboven op gewezen - om de Boschnegers, die in de Surinaamsche maatschappij een belangrijke taak vervullen - als vrachtvaarders, en in mindere mate als houtleveranciers, en die een zekere koopkracht bezitten - van de overige bevolking te isoleeren. Evenmin kan men het vrije verkeer van de beschaafde bevolking met het binnenland belemmeren.

Wat er dan wel moet geschieden?

Dat zal de raad van bestuur en de Malaria-raad hebben te onderzoeken. Een leek moet niet trachten in een tijdschrift, ver van het betrokken gebied, theoretische oplossingen te vinden, die nutteloos zouden zijn in een vraagstuk van den eersten rang, dat slechts door deskundigen, na rijp beraad en ter plaatse, zal kunnen worden opgelost. Als er maar één ding gebeurt! Het gevaar van malaria perniciosa moet in Suriname tot de minst mogelijke afmetingen worden teruggebracht. Caveant consules!

Wij besluiten het betoog met de mededeeling van een driet a 
bijzonderheden, die in het kader van malariabestrijding passen; en geneeskundigen kunnen interesseeren.

I. In 1888 maakte dr. J. Spitzly, chef van den militair geneeskundigen dienst in Suriname met den procureur generaal mr. van Doorn en zijn vrouw, en met den heer en mevrouw Siewerts van Reesema een reis naar de Marowijne tot aan de Merian-kreek, waarbij mr. van Doorn, met zijn ambtgenoot te Cayenne, beiden namens de Gouverneurs overleg zou plegen tot het oprichten van militaire posten, ten einde het stroopen van goud, in het bijzonder in het betwiste Lawa-gebied, tegen te gaan. Gramman Oseisie had de reis van af de monding van de Commewijne tot naar Albina medegemaakt. Te Saint Laurent du Maroni toonde de chef van het hospitaal, dr. Parnet aan dr. Spitzly een geval van „fièvre paludienne fulminante", welke zeer gevaarlijke vorm van malaria, zegt dr. Spitzly op blz. 11 van zijn reisverhaal, opgenomen in het ,JJahresbericht der St. Gallischen Naturwissenschaftlichen Gesellschaft", 1888/1889, alleen door talrijke subcutane injecties van chininum sulfuricum te bestrijden was, daar het proces zeer snel verliep en patienten aan deze koorts meestal in 24 tot 36 uur ondergaan. Ik kan mij niet herinneren, vervolgt dr. S., tijdens een meer als vijfjarig oponthoud te Paramaribo en bijna dagelijksche waarneming en behandeling van malaria-gevallen in de meest verschillende vormen en bij de meest verschillende rassen, ooit dezen vorm te hebben ontmoet. Volgens de mededeelingen van de Fransche artsen, moet de Fransche Marowijne-oever bijzonder ongezond en blootgesteld zijn aan malaria, terwijl, merkwaardig genoeg, de Nederlandsche oever als zeer gezond geldt. De theorie, dat rivieren de verbreiding van malaria kunnen verhinderen, schijnt hier op éclatante wijze te worden bewaarheid.

De oplossing, die dr. Spitzly nog niet weten kon, is natuurlijk, ik behoef het haast niet te zeggen, dat de noord-oost passaat te Albina de muskieten en dus ook de anopheles, weghoudt of verdrijft, terwijl Saint-Laurent, dat niet zoo als Albina een bodem heeft waarop geen plassen blijven staan, door de wouden, jammer genoeg, tegen dien heilzamen wind beschut ligt.

II. Dr. M. Herskovits schreef ons, desgevraagd, op 10 December 1934, dat hij en zijn reisgezelschap niet alleen in Suriname maar ook in West-Afrika en Haïti vrij bleven van malaria, door iederen avond, alvorens te gaan slapen ieder tien ,grains" kinine in te nemen ,I realise this is a terrific dosage, but it seems to do the work". Dr. H. wijst er vervolgens op, dat een bewoner van het land hun voorbeeld niet zou kunnen volgen, want dan, zegt hij 
zou de plasmodie hard worden en zwartwaterkoorts zou volgen. Maar voor lieden die als wij niet langer dan acht of negen maanden achter elkander in de tropen verblijven, schijnt het een heel goede geneeswijze (tot zoover dr. Herskovits).

Wij betwijfelen of elkeen de geschetste voorbehoedmiddel-kuur van $\mathrm{dr}$. H. wel in alle opzichten zal bewonderen. De na-behandeling schijnt onvoldoende of niet doelmatig te zijn geweest; ik meen mij te herinneren, dat hij na zijn terugkeer uit Haïti in de Vereenigde Staten, toch malaria heeft gekregen.

III. Kostbare wenken op het gebied van het voorkomen van malaria geeft de arts H. E. Rombouts in zijn ,"Medische notities over de grensexpedities", die toegevoegd zijn aan,, Op zoek naar Suriname's zuidgrens" door baron A. J. H. van Lynden, met 91 foto's, en 4 kaarten, overdruk uit het tijdschrift Kon. Ned. Aardrijkskundig Genootschap 1939. Ik zou die wenken gaarne in handen willen zien en willen zien opgevolgd door dengene, die zich van uit de kuststreek naar het binnenland moet begeven. De heer Rombouts zegt ongeveer het volgende:

Vast staat, door de proeven van prof. Flu, dat reizigers naar het bewoonde gebied van Suriname's binnenland zich kunnen vrijwaren tegen malaria-infecties door van 's avonds 6 uur tot den volgenden morgen 6 uur in een met muskietengaas afgesloten tent te verblijven. In de praktijk is zoo'n maatregel vrij moeilijk door te voeren en in sommige gevallen (b.v. bij astronomische plaatsbepaling) onmogelijk. Daarom werd de kinine-prophylaxis gekozen die in het Indische leger op patrouilles wordt toegepast, n.l. het dagelijks slikken van 0.4 à 0.5 gram hydrochlorae chinini in pillen en bovendien eens in de week $20 \mathrm{mgr}$ plasmochin. Bij de Surinamers, waarschuwt de heer R. echter terecht, moet men niet met dwangmiddelen aankomen. Na terugkeer te Paramaribo werd de kinine-prophylaxe beëindigd met een kinine- of een Atebrinekuur, gecombineerd met plasmochin, en het resultaat hiervan was zeer goed.

\section{Naschrift.}

Prof. P. C. Flu, hoogleeraar in de Tropische Hygiene en Parasitologie en Directeur van het Instituut voor Tropische Geneeskunde te Leiden, heeft ons vereerd met een exemplaar van zijn Verslag van een studiereis naar Suriname, September 1927-December 1927, Kemink en Zoon, Utrecht. Even mogen wij hier, eveneens met dankbaarheid, gedenken, dat genoemd instituut, dat het Verslag van prof. Flu heeft uitgegeven, ons in de gelegen- 
heid heeft gesteld tijdens den eersten wereldoorlog een college te volgen van den hoogleeraar in de Volkenkunde, en med. dr. A. W. Nieuwenhuis, en verder iets over dat Verslag in het midden brengen. Over malaria handelen twee hoofdstukken: „De malaria in en om de stad Paramaribo in verband met den rijstbouw" en „De malaria in de districten”.

In het tweede genoemde hoofdstuk becijfert prof. Flu, dat alleen aan verpleeggelden de malariapatienten op zes (daar vermelde) plantages, per jaar ongeveer $f 8090$ kosten. Dat is direct geleden geldelijk verlies. Maar omdat men door ziekte de werkkracht van den koelie mist en dat deze dus inproductief is, lijdt de onderneming, het dagloon van den koelie gesteld op 80 cent een niet direct geldelijk verlies, dat even groot is. De verpleging van malarialijders op alle plantages te zamen stelt jaarlijks eischen die zeer groot zijn.

Wil men weten, waarom Suriname niet tot bloei komt, en waarom de ondernemingen er, ondanks den vruchtbaren bodem niet rendeeren, dan heeft men alvast een hoofdoorzaak: de malaria.

Wij wenschen het Verslag van dezen uitnemenden ontdekker en geleerde, van een van Suriname's allerbeste zonen in handen van elk ambtenaar, van ieder beschaafd man, van ieder die het wel meent met het bloei en welvaart behoevende land.

\section{LITTERATUUR:}

L. C. VAN PANHUYS, Belang van het personeel van den Lawaspoorweg bij een bestrijding en voorkoming der malaria, 1903, bekroond door de geneeskundige commissie te Paramaribo met een premie van $f 150$.

H. J. M. Sсноо, arts (en malaria-specialist) te Krommenie, Bekroonde populaire handleiding omtrent malaria, de noodige leefregelen, de middelen ter voorkoming of ter genezing dier ziekte en enkele nuttige wenken voor andere ongesteldheden in de tropen. Paramaribo, 1904, gedrukt ter Algemeene Landsdrukkerij te 's-Gravenhage, $75 \mathrm{blz}$., 5 fig., kl. $8^{\circ}$, prijs $f 0.15$ (was in enkele dagen uitverkocht). Volgens de inleiding werd het geschrift uit 14 oplossingen van een prijsvraag, met den prijs van $f 300$ bekroond, terwijl aan den steller dezes, wiens antwoord het bekroonde zeer nabij kwam, en aan wiens antwoord enkele punten, zooals ankylostomiasis, ter aanvulling werden ontleend, de bovenvermelde premie werd toegewezen. Voorts:

L. C. van Panhuys, , Recent discoveries in Dutch Guiana”, Proceedings Int. Congress of Americanists, Londen, 1912, blz. 374-377, met overzicht van de uitkomsten van het verslag over malariaonderzoek en andere ziekten door den officier van gezondheid P. C. Flu; 
L. C. van Panhuys, ,Een man van de daad, W. C. Gorgas”, W. I. G. II, blz. 355;

Dr. R. RömeR, ,,Sanitaire beschouwingen in verband met immigratie van werkkrachten in Suriname" W. I. G. II, blz. 101, 205, 275, 383, 463, speciaal blz. 105;

C. H. DE GoEJE, ,,Suriname ontdekt, T. A. G. 1934, blz. 31, Panorama uit Teboe, met Tafelberg (Emma-keten);

Prof. dr. N. H. Swellengrebel, ,, Over de vraag of een proefneming tot vestiging van politieke uitgewekenen in Suriname hygienisch te verantwoorden is", met de daarin aangehaalde belangrijke litteratuur, o.a. van dr. C. Bonne, W. I. G. XXII (1940);

E. JUNKER, ,Malaria in Suriname”, W.I.G. XXIII, blz. 23-30. Men raadplege ook het fraaie artikel ,,Malaria”' in de nieuwe encyclopaedie van Winkler Prins. Ik moge hier nog, op gezag van prof. Flu, de aandacht vestigen op den arbeid in Suriname van de heeren doktoren De Ruiter en Lampe. Zie ook De W. I. G. IX, artikel van dr. Lampe.

Post Scriptum.

Onder de vele geschriften over het onderwerp, die wij hebben geraadpleegd is er een, dat nog moge worden genoemd. Jhr. mr. A. E. Elias, secretaris-generaal van het departement van Koloniën zond mij, in 1904 met de woorden: ,,Misschien stelt Gij hierin belang” een omzendbrief van de directie van de zendingsdrukkerij te Ermelo, nopens een boekje over: Malaria, aanwijzingen ter voorkoming en behandeling, rijk geillustreerd, naar het Duitsch van R. Fisch, Dr. Med., ingeleid door J. F. Blom van Geel, arts te Utrecht, 81 bladz., prijs $f 0.75$. Er staat in, hoe en op welke wijze de huisvrouw in Nederlandsch WestIndië het in haar macht heeft de steekmuggen in huizen het binnendringen en het verblijf in de huizen te beletten; er staat een zeer goede beschrijving in van den malaria-aanval, van de verschillende soorten der ziekte, over de behandeling; over de vraag hoe en wanneer men kinine moet innemen; over de ziektebehandeling (blz. 64-81). Dr. Fisch was praktiseerend geneesheer aan de Goudkust (West-Afrika), die met zijn rijke ervaring, opgedaan in dit beruchte malaria-gebied, allereerst zijn jongere collega's wilde dienen. Tevens echter dacht hij aan de breede schare ambtenaren, zendelingen en kooplieden, die dikwijls op eenzame posten verstoken zijn van alle geneeskundige hulp.

Gedachtig aan: ,,de vrouw in West-Indië”, willen wij iets over hetgeen in dit boekje staat, nog als postscriptum laten volgen. Op wie komen de zorg en de last van verpleging bij ziekte in hoofdzaak neder? Op moeder de vrouw!

$\mathrm{Zij}$ moet, desverkiezende, gerust kunnen overslaan, wat in het bovenstaande is vermeld over de ingewikkelde geschiedenis van de plasmodiën, over vraagstukken van natuurlijke historie, over kwesties van bestuur en van maatschappelijke toestanden. Maar de gezondheid van haar gezin, van de kinderen, de verpleging in huis, dat raakt haar in het bijzonder. Dáár is zij de bondgenoote van den arts, de uitvoerster van zijn voorschriften. De vrouw kan een belangrijk deel van de volksgezondheid bevorderen. Te meer indien, zooals ik vrees dat in Suriname totnogtoe het geval is geweest, de heeren der schepping in 
het behartigen van dit onderwerp in belangrijke opzichten hebben gefaald.

Wij geven nu, uitsluitend voor de vrouw, de volgende raadgevingen van dr. Fisch.

1. Zwangere vrouwen moeten zeer voorzichtig zijn met kinine, en in dien tijd het innemen van groote hoeveelheden nalaten.

2. Geef kinine korten tijd, 6-12 of 20 uur na de koorts.

3. Het is een groote fout, vóór den koortsaanval kinine in te nemen. Vóór de koorts bevinden de malaria-parasieten zich in milt en beenmerg, en in dien tijd zijn ze voor kinine ontoegankelijk. Neemt men, verkeerdelijk, kinine vóór den koortsaanval, dan kan men licht zwartwaterkoorts krijgen. Men moet niet de naderende koorts behandelen, maar de haar veroorzakende malaria-parasieten op het juiste oogenblik dooden.

4. Vrouwen en kinderen zijn veel meer aan huis gebonden dan de man, maar juist in huis kan de anopheles zich ophouden en daardoor lijden dikwijls vrouwen en kinderen meer en zwaarder aan malaria dan de man. De besmetting gaat dikwijls in dezelfde kamer van mensch op steekmug over, en omgekeerd.

5. Let op of uw kinderen bleek zien en, ongemerkt, aan koorts lijden.

6. Wees nimmer bevreesd uw kinderen, volgens 't voorschrift van uw huisarts kinine te geven; kinderen verdragen kinine even goed als volwassenen.

7. Dek een malaria-zieke, die koude rillingen krijgt, warmpjes toe, en geef hem of haar wat flink heete thee. Duurt de koude zeer lang en is zij zeer hevig, dan verwarme men het bed met een warme kruik.

8. Wees niet bevreesd, indien het lichaam op een malaria-aanval met een krachtige koorts reageert. Denk er aan, dat antipyrine den parasieten niet kan deren; integendeel slechts gunstig voor de parasieten kan werken.

9. Duurt het hitte-stadium bij den lijder te lang, dan make U een natten omslag door den lijder te hullen in een met lauw water nat gemakt laken en door stijf in een groote wollen deken te wikkelen.

10. Bij terugkomende koortsen ${ }^{1}$ ), voorzichtig met kinine gebruik. Dr. F. raadt bij zulk een koorts, vooral wanneer urine en stoelgang in 't oogloopend donker gekleurd zijn en het wit van het oog een gele tint vertoont, den eersten dag $4 \times 0.2$ gr.; den tweeden dag $5 \times$; den 3 den dag $6 \times$; den 4den 7 tot 8 maal 0.2 gr; en ga daarmede nog een paar dagen lang voort. De werking der vorige dosis moet nog niet geheel voorbij zijn, als die der volgende reeds begint. Op die wijze is het dr. F. reeds dikwijls gelukt, lijders van hun koorts te genezen, terwijl deze anders naar geen enkel middel wilde luisteren.

11. Als eerste voorwaarde bij braken geldt, volstrekt niets in de maag te brengen en den lijder volmaakt stil in bed te laten liggen.

12. Plaagt den kranke een min of meer groote onrust, dan volstrekte rust in en rondom het huis. Elk rumoer of gedruisch vermijden. Geen slechte tijdingen mededeelen. Moed geven. Mocht er ernstig gevaar

1) Deze ,,remitteerende" koortsen treden op, indien men op verschillende tijdstippen door besmette muskieten mocht zijn gestoken. 
zijn, dan is het zeggen van de waarheid voor de verpleegster (evenals voor den geneesheer, maar die weet die dingen beter dan $U$ en ik) een heilige plicht, met dien verstande natuurlijk, dat men zeker zij van zijn zaak.

13. $\mathrm{Bij}$ onmacht, den zieke volkomen plat op het bed leggen, zoo mogelijk met het hoofd nog lager dan de voeten, den hals geheel ontdoen van benauwenden kleedingstukken. Maatregelen nemen tot verkorting van het tijdperk der koude rillingen, en van het tijdperk der groote hitte (zie punt 6 en 8 ). Hoffmann's-druppels of eenige druppels krachtige spirituosa. In hoogst ernstige gevallen : alcohollavement (een eetlepel sterk alcoholicum met gerstenat).

14. Bij hevige hoofdpijnen, of koude omslagen, òf een dosis antipyrine.

15. Steenpuisten (die zooals U misschien weet, slechts dáárdoor kunnen ontstaan, doordat zwammen zich van buiten in de geopende zweetporiën dringen) voorkomen, door afwasschingen met goede brandewijn.

16. Voeding der kranken, indien de koortsen langer dan 6 uur duren: eiwit met suiker en $\frac{1}{2}$ eetlepel cognac, geklutst in een glas water, $3 \times$ per dag; melk met koolzuurhoudend mineraalwater; amandelmelk met suiker en oranje-bloesem- of laurierkerswater. Geen alcoholica als drank; wel rijnwijn met water en suiker; ook citroensap met water en suiker.

Een bijzondere wenk voor moeders.

Kleine kinderen en zuigelingen worden dikwijls in hun bedje of kinderwagen slapend, zonder eenige bescherming aan de steekmuggen blootgesteld. Men laat ze in de morgen- of avondkoelte in kamer of op veranda slapen, zonder te bedenken dat zij, omdat zij stil liggen, bijzonder in gevaar zijn van door muggen te worden gestoken. 't Is dus volstrekt noodig de kinderwagens te voorzien van een voldoende bescherming tegen muggen, anders kan 't voorkomen, dat een kind malaria krijgt, hoewel het 's nachts uitstekend tegen muggen beveiligd is, alleen omdat men er niet genoeg op lette, dat slapenden ook overdag en vooral 's morgens vroeg of 's avonds allicht kunnen gestoken worden. Het muskieten-gaas of -net moet over rieten bogen gespannen en goed sluitend aan het wagentje bevestigd worden.

Wenken voor de huisvrouw.

Leer uw bedienden de steekmuggen in huis te dooden. De steekmuggen houden niet van licht en wind. Duldt geen schuilhoeken in de buurt van uw huis, waar ze zich in de open lucht onder de bladeren van boomen en struiken verbergen. Richt uw kamers zoo in, dat de lucht er door stroomt. Laat de wanden met kalk bestrijken of wit schilderen. Vermijd het gebruik van open kasten, boekenrekjes, gesloten schrijftafels, inrichtingen om kleederen op te hangen, droge grasbouquetten en gordijnen. Bevestig schilderijen of tegels sluitend tegen den wand. Zorg dat nergens tochtvrije, donkere hoeken ontstaan. Haal uw man er toe over het geheele huis met draadnet tegen muskieten te beveiligen; de kosten haalt u er uit, door vermijding van ziekte, door vermeerdering van gezondheid en levensvreugde. Dring er op aan, dat uw man in zijn 
bureau tegen muskieten is beschermd, en zorg dat hij ook thuis een muskietenvrije studeerkamer heeft.

Hoe kan $u$ bemerken, dat een malaria-aanval in aantocht is?

Allerlei voorboden gaan vooraf. De eetlust is gestoord (soms in 't oogloopend vermeerderd). De slaap is onrustig, dikwijls van zware droomen vergezeld. De huid voelt onplezierig droog aan; men voelt trekkingen in de ledematen. Men gevoelt zich lusteloos om te werken; soms is er vermeerderde prikkelbaarheid, verdrietige stemming; bij anderen ongewone vroolijkheid en spraakzaamheid. Van tijd tot tijd voelt men een zeer flauwe rilling, een onaangenaam koud gevoel. Men moet het werk opgeven. Aanwezige hoofdpijn wordt steeds erger; de koude rillingen worden menigvuldiger en houden langer aan. Gaat men naar bed, dan doet het ontkleeden en de aanraking met het beddegoed een , koude-koorts" ontstaan, die niet zelden een vol uur duurt en waarin de kranke begint te klappertanden. Zeer dikwijls komt deze koude koorts, indien men niet naar bed is gegaan, zeer plotseling op, zoodat de zieke en zijn huisgenooten er geheel door worden overrompeld. Zeer dikwijls vertoont zich ook tevens de misselijkheid.

Verder verloop van den malaria-aanval.

In zeer korten tijd stijgt de lichaamstemperatuur, tot zeer hoog, waarover men zich niet ongerust moet maken. De lijder kan er vreeselijk bleek en vervallen uitzien. Na eenigen tijd, van een kwartier tot twee uren toe, houdt het gevoel van koude op. Zeer langzaam ondervindt het lichaam een weldadig warm gevoel, als van een aangenaam warm bad. De zieke gaat over in het zoo veel aangenamer tijdperk van hitte. Heeft men hoofdpijn, dan wordt deze ondragelijk. De huid wordt, in plaats van bleek, allengs rood. Er kunnen hartkloppen, duizeligheid ontstaan. Eindelijk begint het tijdperk van het zweeten. Een weldadig gevoel ontspant den lijder; men doet droge kleeren aan, gaat op een ander bed liggen en krijgt zeer spoedig weer nieuwe arbeidslust. Als het merkwaardige van malaria-aanvallen komt bijna altijd de opvallend snelle genezing. De bovenstaande schets is van een eersten malaria-aanval. Heeft men reeds verscheidene aanvallen medegemakt, dan kan het beeld anders zijn. 